\title{
26. A New Find of Encrinurus from Japan.
}

\author{
By Toshio Sugryama. \\ (Comm. by H. YABE, M.I.A., April 12, 1941.)
}

In a recent paper $^{1}$, the writer reported on the occurrence of a trilobite under the name of Encrinurus kitakamiensis without any description or figure from Kusayami-zawa at the southern foot of Takainari-yama, Hikoroiti-mura, Kensen-gun, Iwate-ken. The several pygidia obtained from the black limestone in the upper part of the 2nd horizon of the Kawauti series ${ }^{2}$ are often found in association with a brachiopod probably referable to Plectambonites. At first, this fossil was referred to Encrinurus (sens. ext.), a genus flourished in the Ordovician and Gotlandian. However, later study reveals that the present pygidia bear many characters reminding one strongly of Coronocephalus, a subgenus of Encrinurus established by A. W. Grabau ${ }^{3)}$ in 1923 on Encrinurus (Coronocephalus) rex Grabau from the Sintan Shale of Hupeh province in the Central China.

The comprehensive study of Coronocephalus by Y. Wang ${ }^{4)}$ has recently made clear the subgeneric status. According to him it is a trilobite monotypic at present, and its genotype has an extensive geographical distribution in China, being known from Kueichow, Szechuan, Hupeh, Kiangsi, Anui, and Kiangsu provinces; geologically it is restricted to the Sintan Shale of China. The subgeneric diagnosis given by Wang is as follows: "Cephalic shield sublunate to subtriangular in outline, with the genal angles produced backward into long spines beyond the posterior end of the carapace. Glabella clavate, carrying three deep and broad transverse furrows and three nodular lobes in its narrower part. Whole surface of the cephalon coarsely tuberculated.

1) T. Sugiyama: Stratigraphical and paleontological studies of the Gotlandian deposits of the Kitakami Mountainland. Sci. Rep. Tôhoku Imp. Univ. Sec. Ser. (Geol.), vol. 21 , No. 2, p. 90 .

2) The succession of the Gotlandian deposits developed at Kusayami-zawa is as follows (T. Sugiyama, op. cit., pp. 89-91):

B. Takainari series (Upper Gotlandian)

2. Chiefly composed of green adinole containing many radiolaria, crossbedding distinct in corase grained part; $150 \mathrm{~m}$.

1. Reddish purple, occasionally greenish radiolarian slate; $18 \mathrm{~m}$.

A. Kawauti series (Middle Gotlandian)

3. Solenopora limestone, a grey or black limestone; $4 \mathrm{~m}$.

2. Encrinurus bed, composed of thin-layered alternation of black slate and grey impure limestone; $5 \mathrm{~m}$.

1. Halysites limestone, composed of impure grey-black limestone, considerably slaty at places; $6 \mathrm{~m}$. 132.

3) A. W. Grabau: Stratigraphy of China. Part 1, Palaeozoic and older, pp. 131-

4) Y. Wang: The Lower Silurian Trilobite Encrinurus (Coronocephalus) rex, its geographical distribution and stratigraphical position. Bull. Geol. Soc. China, vol. 18, No. 1, pp. 21-28, 1938. 
Thorax with eleven segments. Pygidium triangular; axial rings much more numerous than the pleurs, well marked in the sides and weakened at the middle."

As stated by Wang, Coronocephalus bears many superficial alliances to Encrinurus (sens. str.), particularly to Reed's third group ${ }^{1)}$ by having a coarsely tuberculated cephalon and nodular glabella lobes. He, however, distinguished the Chinese form from Encrinurus (sens. str.) by the genal spines which are exceedingly long and produced backward, and by the broad transverse furrows of glabella.

The Japanese material is represented by pygidia only, whose characters run as follows: the pygidium is large triangular in outline, wider than long. The rachis is gradually attenuated posteriorly, well defined from the pleural area, and has annulations which are considerably more numerous than the pleurs, conspicuous at sides and rather weakened at the middle.

Reed's third group of Encrinurus (sens. str.) is related to the present material, but two are considerably different from each other in the annulations of the rachis ; namely, in the former, they are usually complete, neither well marked at sides nor weakened at the middle. Thus the Japanese form evidently possesses characters of pygidium more related to Coronocephalus than to any groups of Encrinurus (sens. str.).

The present record of Coronocephalus, which is the first in Japan, is particularly interesting since it extends the known geographical distribution of the subgenus and moreover, it is an important element in

1) F. R. C. Reed divided the known species of Encrinurus into six different groups (Notes on the Family Encrinuridae. Geol. Mag. Vol. 65, pp. 66-67, 1928) :

1. Pygidium with complete axial rings, considerably more numerous than the pleurae. Cephalon with distinctly lobed glabella, lateral furrows clearly marked; lateral lobes sometimes nodular. Genal angles pointed. Ex.: E. sexcostatus Salt. Range: chiefly Ordovician.

2. Pygidium with complete axial rings, few and equal in number to or not much more numerous than the pleurae. Cephalon coarsely tuberculated, with lateral lobes and furrows of glabella obscure or absent. Genal angles rounded. Ex.: E. variolaris Brong. Range: Silurian.

3. Pygidium with very numerous complete axial rings. Pleurae fewer in number than rings. Cephalon coarsely tuberculated. Lateral lobes of glabella nodular. Ex.: E. platynodus Mitch.

4. Pygidium with numerous rings on axis, of which the anterior rings are complete, but the posterior ones are interrupted or weakly marked in the middle. Cephalon with glabella coarsely tuberculated; lateral lobes nodular. Ex.: $E$. multisegmentus Portl. Range: Upper Ordovician.

5. Pygidium with numerous narrow axial rings, all (or nearly all) incomplete and discontinuous, with smooth median space for whole length of axis, usually ornamented with row of tubercles fewer in number than the rings. Cephalon with glabella coarsely tuberculated and lateral lobes usually nodular. Ex.: $E$. punctatus Brunn. Range: Silurian.

6. Pygidium with axial rings continuous or discontinuous. Pleurae with free spinose ends. Cephalon with glabellar furrows distinct. Eyes sessile, close to glabella. Thorax of ten segments. Ex.: E. (Cromus) intercostatus Barrande. Range : Silurian, 
the correlation between the Sintan Shale of China and the Gotlandian deposits of the Kitakami Mountainland.

\section{Encrinurus (Coronocephalus) kitakamiensis Sugiyama}

Figs. 1-2

Pygidium triangular in outline, wider than long and gently convex. Rachis well defined by the marked dorsal furrows, depressedly convex and tapering uniformly toward an acute termination; composed of more than thirty annulations or rings of which the several posterior ones are poorly marked. Ten anterior rings distinct, particularly well marked near the lateral margins of rachis, but indistinct in the median region, while the others are fused along the most convex portion of the rachis, thus forming a smooth ridge along its top. Lateral ribs or pleurs composed of more than 10 simple or unfurrowed lobes without ornamentation, separated by deep and sharp groove; discontinuous with those of the rachis ; anterior ribs gently curved backward, widening laterally, while the posterior ones become more and more oblique as they approach the posterior end, thus the last two are arranged nearly parallel to the basal end of the rachis.

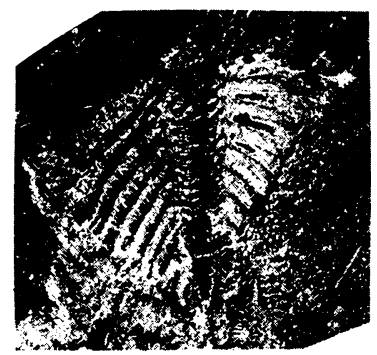

Fig. 1. $\times 1$

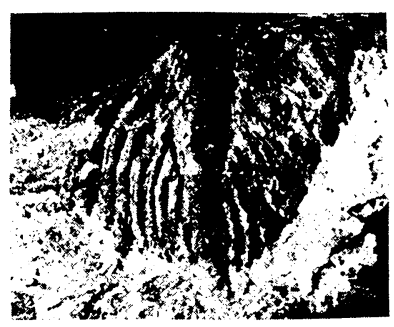

Fig. 2. $\times 1$

Encrinurus (Coronocephalus) kitakamiensis sp. nov.

Loc. Kusayami-zawa at the southern foot of Takainari-yama, Hikoroitimura, Kesen-gun, Iwate-ken. Reg. No. 61513.

The above description was based on a specimen shown in Fig. 1. This specimen is considerably deformed, and particularly so on the pleural portion in the left side, but reveals the essential characters necessary for its specific identification; it is large and about $35 \mathrm{~mm}$ broad and $30 \mathrm{~mm}$ high. There are several other incomplete pygidia of the same species at hand, and one of them is shown in Fig. 2. This second specimen is somewhat broader than the first one, being about $40 \mathrm{~mm}$ broad and $25 \mathrm{~mm}$ high; the ribs in the posterior portion are comparatively well preserved, in their arrangement nearly parallel to the basal end of the rachis, and shortly pointed in the pleural ends.

Comparing with Coronocephalus rex Grabau, the present form is apparently indistinguishable, but a close examination shows that the pygidium of the latter is larger in size and yet has less numerous annulations of the rachis. According to Wang, the Chinese form has as 
many as 35-45 annulations, and its size does not exceed $25 \mathrm{~mm}$ broad and $20 \mathrm{~mm}$ high even in the largest specimen.

Finally, the writer wishes to express his warmest thanks to Dr. H. Yabe, Prof. Em. of the Tôhoku Imperial University to whom he is much indebted in the preparation of this short paper and to $\mathrm{Mr} . \mathrm{K}$. Hatai of the same Institute for reading the manuscript. 